\title{
Comparison of Some Approaches to Determine Spatial Dependence of Soil Properties
}

\author{
Manoj K. Shukla, \\ New Mexico State University, Department of Plant \\ and Environmental Sciences, MSC 3Q, P.O. Box \\ 30003, Las Cruces, NM 88003-8003. Tel: 575-646- \\ 2324; Fax: 575-646-6041; e-mail: \\ shuklamk@nmsu.edu.
}

*Corresponding author: Blair L. Stringam, Department of Plant and Environmental Sciences, New Mexico State University, MSC 3Q, P.O. Box 30003, Las Cruces, NM 88003-8003. Tel: 575-6467665; Fax: 575-646-6041; e-mail:blairs@nmsu.edu

\begin{abstract}
Knowledge of variability and spatial structure of soil properties is essential for optimal design for collecting soil samples and effectively applying management decisions in the field. The objective of this study is to compare some approaches for characterizing, and comparing spatial dependence of isotropic second-order stationary processes. The evaluated approaches are the nugget to sill ratio (NR), normalized (by fitted sill) semivariogram, correlograms, and two integral scales. Soil samples, collected at a regular $50 \mathrm{~m} \times \mathbf{5 0} \mathrm{m}$ grid from 0-15 cm depths, were analyzed for sand and clay, bulk density $\left(\rho_{b}\right)$, saturated hydraulic conductivity $(K s)$, wilting point, available water content (AWC), pH, electrical conductivity (EC), nitrate-nitrogen (NO3- $\mathrm{N})$, and chloride $(\mathrm{Cl})$ were determined. Geostatistical software (GS+, Gamma Design Software, Plainwell, MI) was used to estimate the variance structure of various measured soil properties. Analysis include using data on the spatial variability of various properties from four published studies. NR displayed spatial dependence ignoring the influence of range, normalized semivariogram and correlogram provided the visual comparison, and both integral scales incorporated the influence of range and provided single number spatial dependence summaries. Either of the integral scale formulations can be used to characterize the spatial dependence of soil properties from agricultural fields.
\end{abstract}

Key Words: Spatial variability, nugget to sill ratio, integrated scale, correlogram,

DOI: $10.5176 / 2345-7848 \_3.1 .18$

\author{
Dawn M. VanLeeuwen, \\ Agricultural Biometric Service, New Mexico State \\ University, Las Cruces, NM, USA-88003. Tel: 575- \\ 646-7691; Fax: 575-646-1915; e-mail: \\ vanleeuw@nmsu.edu.
}

Parmodh Sharma, New Mexico State University, Department of Plant and Environmental Sciences, MSC 3Q, P.O. Box 30003, Las Cruces, NM 88003-8003.

\section{INTRODUCTION}

Soil survey reports provide information on various soil properties and their spatial distribution on a large scale for most of the counties of the USA. However, precision farming, designing site-specific management practices, and simulation modeling demand soil data at a more detailed scale than available in these reports. Thorough on-site sampling across the mapping units, land uses and management practices provides such data [1]. Accurate and detailed data are a prerequisite to precisely model vadose zone processes, such as retention and transport of water and solute [2]. Variability of soil properties is usually associated with spatial, temporal or management related factors and are strongly influenced by the relative magnitude of each source of variability as well as their combined effect [3]. Variance or a semivariogram function express variability of a soil property [4]. Geostatistical tools are commonly used for estimating the semivariogram function to characterize the spatial variability of soil properties [5], [6], [7]. Using existing geostatistical tools, the variability of soil properties and spatial dependence are reported for scales ranging from a few meters to several kilometers [8], [9], [10], [11], [12]. 
The spatial variability analysis has several applications, it can be used to delineate areas into, for example, mapping contiguous patches of sodium contents or hydraulic conductivities [13]. Spatial variability analysis can also be done to design a strategy for collecting a limited number of spatially independent samples for future analysis [14]. While it may be more appropriate to look at the correlations at shorter lag intervals for the former or mapping exercise, it may be more appropriate to look at the larger lag intervals or the range for the latter. However, knowledge of the complete variogram is useful to make both decisions and understand the spatial structure of soil properties.

Several methods can be used to classify spatial dependence of soil properties [15], [16], [17], [18], [19]. This paper includes: nugget to sill ratio (NR), relative structured variability (RSV), normalized semivariograms and correlograms, and integral scales [17], [20]. NR is based on the interpretation of variogram parameters and is commonly used to classify the spatial dependence of a soil property as strong $(\mathrm{NR} \leq 0.25)$, moderate $(0.25<\mathrm{NR}<0.75)$ or weak (NR $\geq 0.75)$ [17]. The NR successfully classified spatial dependence of soil properties in several studies ([21], [22], [23], [24], [25]. Information of spatial structure is also associated with the range of spatial correlation of a soil property but NR approach largely ignores it. The relative structured variability (RSV) is the degree to which variability is spatially structured [19] and is related to the NR through the relationship RSV=1-NR. Thus, the RSV, range and the semivariogram model all contain information about the degree of spatial structure [19].

The degree of spatial structure is affected by more than one parameter or feature of the model and classifying and comparing spatial dependence of multiple processes can be complicated. Semivariograms provide visual summaries of spatial correlation and incorporate estimated semivariogram models and incorporate information on both variability and spatial structure. However, these graphs, although display range, do not provide a straightforward or simple comparison of the spatial structure of two processes and therefore are not usually used to classify spatial dependence. Plotting correlations as a function of distance provides a correlogram. They provide a sort of spatial dependence profile and provide a basis for visually comparing spatial structures rather than using semivariograms [26].

Integral scales provide a single number estimate of spatial dependence and incorporate information from all three facets of the estimated empirical semivariogram. They estimate the average distance for which observations are correlated and indicate the distance within which observations are highly correlated [15], [19], [27].

A closer examination of the semivariograms and integral scales show that both reflect the scale of measurement of the response variable. Consequently, integral scales can compare the spatial dependence of processes where distances have been measured on the same grid spacing and size of the fields. However, because of the scale influence on which distance is measured, NR is much easier for classifying spatial dependence. Even if distances have been measured on the same scale, using semivariograms to compare spatial dependence of different properties is complicated because semivariogram contains information about the response variability and spatial structure. This paper discusses approaches to exploring, characterizing, and comparing spatial dependence of isotropic second order stationary spatial processes.

\section{MATERIALS AND METHODS}

This study utilized the data collected from research conducted on an agricultural land area near Las Cruces, New Mexico [14]. Also, data were used from four published studies including, [11], [12], [17], and [28]. Selected data were from different regions and at different grid spacing. The purpose of data collection in these studies could be assumed different because attributes (or soil properties) determined were different. Various studies employ different sampling schemes. For example, one of the studies measured soil properties at $2 \mathrm{~m}$ lag distances enabling the nugget effect to be fitted to represent variation at less than $2 \mathrm{~m}$ lags. In contrast, another study has the shortest separation distance of $25 \mathrm{~m}$, meaning that the nugget effect has to capture more variation. The experimental fields were of different size and scale of measurement of response variables were different among sites. In this study, comparison of various soil properties was made only to emphasize the role of range and spatial dependence determined by any given approach. For a given soil property, we also compared approaches for characterizing spatial dependence.

\section{Experimental Sites, Soil Sampling and Laboratory Analysis}

The study site for [14] was a 40 ha land area located at the Leyendecker Plant Science Research Center (LPSRC) near Las Cruces, New Mexico (32 $11.46^{\prime}$ $\mathrm{N}$ and $\left.106^{\circ} 44.30^{\prime} \mathrm{W}\right)$. The crops in the study area were cotton (Gossypium spp.), sudan grass (Sorghum 
sudanense), chile (Capsicum annuum L.), onion (Allium cepa L.), and pecan (Carya illinoinensis (Wangenh.)). The dominant soil types at the study site were Armijo (fine-silty, mixed, calcareous, thermic typic Torrifluvents) and Harkey (coarse-silty, mixed, calcareous, thermic typic Torrifluvents) series [29]. The average annual precipitation for the site was $25.4 \mathrm{~cm}$, and the average annual temperature was $17.7^{\circ} \mathrm{C}$. The Rio Grande river flows $85 \mathrm{~m}$ from the northwest border of the site, and a drainage ditch is $15 \mathrm{~m}$ away from the east side of the area. The irrigation for the entire experimental site is using both ground and surface water. The study area comprised twelve agricultural fields under the same crop rotation scheme since 2010 [14]. Core and bulk soil samples were collected at the center of a regular grid with a separation distance of $50 \mathrm{~m}$ (151 samples) and at 2-, 5-, 10-, and 15-m intervals (135 samples) on some grid lines from $0-15 \mathrm{~cm}$ depth during Nov. 2008 and 2009. Non-normal data were transformed using a natural logarithm before geostatistical analysis.

Reference [17] used a square grid sampling scheme to collect soil samples from $0-20 \mathrm{~cm}$ depth at $25 \mathrm{~m}$ increments from an area of $250 \mathrm{~m} \times 250 \mathrm{~m}$ (total 121) in southern Boone County, Iowa. We also collected additional secondary samples at 2, 5, and $10 \mathrm{~m}$ intervals (total 120) to account for shorter range variability by providing a minimum lag distance of 2 m. Non-normal data were log-transformed. Similarly [11] collected 60 soil samples from a loam soil at 0 to $15 \mathrm{~cm}$ depth with $50 \mathrm{~m} \times 25 \mathrm{~m}$ grid design at the 7.5 ha experimental area of the University of Agricultural Sciences Vienna, Gross-Enzersdorf, Austria. Geostatistical analysis used original data. Reference [28] collected a total of 209 soil profiles near Perthshire, MS at a mean distance of $79.4 \mathrm{~m}$ apart from 18 parallel transects on 162- ha cotton field. Major soil types are Commerce (fine-silty, mixed, superactive, nonacid, thermic Fluvaquentic Endoaquepts), Robinsonville (coarse-loamy, Rabenmixed, superactive, nonacid, thermic Typic Udifluvents), and Convent (coarse-silty, mixed, superactive, nonacid, thermic Fluvaquentic Endoaquepts). These samples determined several soil physical parameters, the variance structure, and ultimately the soil sampling strategy of the alluvial floodplain soils. Before the geostatistical analysis, significantly skewed variables were log transformed. Reference [12] used an irregular grid design (with 40 samples on $100 \times 100 \mathrm{~m}$ grid) to collect soil samples in middle black sea region Turkey at 94 sampling locations in a 45- hectare area from 0-20 cm and 20$40 \mathrm{~cm}$ depths, separately. The soil was Typic Ustifluvents (mostly clay) according to [30]. Soil properties determined include particle size distribution, gravimetric water content, bulk density, and penetration resistance on samples collected from 0-20 cm depth. Non-normal data was log transformed prior to the geostatistical analysis. Standard laboratory methods determined the soil sampling and soil properties presented in [17], [11], [28], [12], and [14].

\section{Semivariogram models}

Geostatistical tools including semivariograms and autocorrelations were used to determine the degree of spatial variability for each measured soil attribute (for example, [31]). Geostatistical software (GS+, Gamma Design Software, Plainwell, MI) was used to obtain the semivariograms for each measured soil variable. Theoretical variograms obtained by fitting spherical, exponential, and Gaussian models. A model was selected based on the least residual sum of squares between experimental and theoretical semivariograms and also using the correlation coefficient $\left(r^{2}\right)$ values for each soil property. Spherical and exponential models were the best fit models to the semivariograms of the measured soil properties, therefore, for the present study; we will only focus our discussion on the spherical and exponential semivariogram models. The spherical model is represented by:

$$
\begin{array}{rlrl}
\gamma(h) & =0 & & \ldots . . \text { for } h=0 \\
& =C_{0}+C_{1}\left[\frac{3 h}{2 a}-\frac{h^{3}}{2 a^{3}}\right] & & \ldots . . \text { for } 0<h \leq a \\
& =C_{0}+C_{1} & & \ldots . . \text { for } h>a \\
& \text { Eq. } 1 &
\end{array}
$$

where $\mathrm{h}$ is lag distance; $\mathrm{C}_{0}$ is the nugget effect, which is the local variation occurring at scales finer than the sampling interval or fine scale variability, measurement or sampling error; $\mathrm{C}_{0}+\mathrm{C}_{1}$ is the sill or total variance; and $a$ is range of spatial dependence, the distance at which the semivariogram levels off to reach the sill value and beyond which sampling variables are not correlated [20].

A frequent interpretation of the nugget is that it is the semivariance at a distance of zero. However, by definition, both theoretical and empirical semivariograms attain a value of zero at $h=0$. Measured values of a variable can be different at very small separation distances mainly due to the sampling error or fine scale variability. Therefore, nugget variance is also reported to be due to the variability occurring at a scale smaller than the sampling scale. It is also reported to be due to measurement errors [32]. When this occurs, a nugget effect is present, and the semivariogram exhibits a jump (or 
discontinuity) after the origin [20]. When there is no nugget effect $\left(\mathrm{C}_{0}=0\right)$, the empirical correlation function for the spherical semivariogram model is:

$$
\begin{aligned}
\rho_{0}(h) & =1-\left[\frac{3 h}{2 a}-\frac{h^{3}}{2 a^{3}}\right] & & \text { for } 0 \leq h \leq a \\
& =0 & & \text { for } h>a
\end{aligned}
$$

Eq. 2

When the nugget is nonzero, the correlation function becomes:

$$
\begin{array}{rlrl}
\rho(h) & =1 & & \ldots . . f \text { for } h \\
& =0 \\
& =(1-N R) * \rho_{0}(h) & & \ldots . . \text { for } h>0
\end{array}
$$

Eq. 3

A nugget effect implies a discontinuity at the semivariogram origin and a discontinuity in the correlogram. The exponential model is as follows:

$$
\begin{aligned}
\gamma(h) & =0 & \ldots . . \text { for } h=0 \\
& =C_{0}+C_{1}\left[1-\exp \left(\frac{-3 h}{a}\right)\right] & \ldots . \text { for } h>0
\end{aligned}
$$$$
\text { Eq. } 4
$$

When $\mathrm{C}_{0}=0$, the correlation function is :

$$
\rho_{0}(h)=\exp \left[\frac{-3 h}{a}\right]
$$

Eq. 5

For $\mathrm{h}>0$, (1-NR) provides an upper bound on the correlation and when the semivariogram form and range are the same, it is reasonable to use NR to classify spatial dependence. However, the estimated range can also differ along with the semivariogram model, and use of NR may be inadequate.

\section{Integral Scales}

Integral scales, while not unitless, provide a single number summary of the distance within which observations are highly [27], [33], [19]. Higher integral scale values indicate higher degrees of spatial dependence or structure. Two forms of integral scales have appeared in the literature ( [15], [19], [27], [33]):

$$
\begin{aligned}
& J_{1}=\int_{0}^{\infty} \rho(h) d h \quad \text { and } \\
& J_{2}=\left\{2 \int_{0}^{\infty} \rho(h) h d h\right\}^{1 / 2} \\
& \text { Eq. } 6
\end{aligned}
$$

According to [27], $\mathrm{J}_{1}$ applies to one-dimensional second-order stationary processes while $\mathrm{J}_{2}$ applies to two-dimensional isotropic second-order stationary processes. Reference [34] applied $\mathrm{J}_{1}$ to twodimensional data also.

Reference [27] conducted simulation studies and explored the properties of the integral scale $\mathbf{J}_{2}$ and noted that transect sampling may result in underestimating $\mathbf{J}_{2}$ [15]. They also computed $\mathbf{J}_{2}$ two ways - based on the empirical semivariogram and based on a fitted exponential semivariogram and found estimates based on the fitted semivariogram to have a smaller bias. For the spherical model when there is a nugget effect:

$$
\begin{array}{ll}
J_{1}=(1-N R) *\left(\frac{3}{8}\right) * a & \text { and } \\
J_{2}=\sqrt{0.2 *(1-N R)} * a & \text { Eq. } 7
\end{array}
$$

Note that as the nugget increases relative to the sill, $\mathbf{J}_{1}$ decreases faster than $\mathbf{J}_{2}$ and so in a sense is penalized more severely than $\mathbf{J}_{2}$. For the exponential model when there is a nugget effect:

$$
\begin{array}{ll}
J_{1}=(1-N R) *\left(\frac{a}{3}\right) & \text { and } \\
J_{2}=\left(\frac{\sqrt{(1-N R) * 2}}{3}\right) * a & \text { Eq. } 8
\end{array}
$$

When there is no nugget effect, in the Eq. 7 and 8, $\mathrm{NR}$ is equal to 0 .

\section{RESULTS AND DISCUSSION Nugget Ratio}

The nugget ratio for various soil properties determined in all five studies are in Tables 1-5. According to the [17] classification, the spatial dependence of some properties in Tables 1, 2 and 5 ranged from strong to weak ([14], [17], and [12], respectively). For the [11] study, NR was always greater than 0.38 and spatial dependence ranged from moderate to weak (Table 3). For [28], NR was between 0.18 and 0.33 , and spatial dependence ranged from strong to moderate. Both exponential and spherical models provided the best fit for soil properties under investigation. Four out of five studies include clay content, and the best fit spherical model range varied from 109 to $379 \mathrm{~m}$. Four out of five studies reported a spherical model as the best-fit for soil bulk density with the range varying from 106 to $433 \mathrm{~m}$.

In [14], the spatial variability of EC was strong in 2008 but moderate in 2009, $\mathrm{pH}$ and $\mathrm{Cl}$ displayed 
strong, and $\mathrm{NO}_{3}-\mathrm{N}$ displayed moderate spatial dependence during the two measurement years. The range of dependence for $\mathrm{pH}$ and $\mathrm{Cl}$ were similar during the two measurement years and correlated with low $\mathrm{pH}$ and $\mathrm{Cl}$ variability among fields. Tables 1 to 5 indicate that even though soil properties were on a regular grid in each study, range of dependence displayed a large variability among various attributes included in a given study. Overall no definite patterns were detected between NR and the range for the data presented in Tables 1 to 5. Pooling all the data from Tables 1 to 5 also did not provide any correlation between NR and range (figure not shown).

\section{Normalized Semivariograms and Correlograms}

Dividing semivariance by their respective sills then plotting them on the same graph essentially removes the influence of variance and response variable scale and retains semivariogram information about spatial dependence; that is, for isotropic second-order stationary processes the normalized semivariogram simply provides an alternative representation of the spatial dependence profile. Since correlograms start at one at zero lag distance, it is easier to plot correlograms of different soil properties and visually see or compare their spatial structure. Plotting normalized semivariogram (semivatiance/total sill) with respect to the lag distance provides the same advantage. However, these two do not provide a single number estimate as provided by the NR or RSV.

Figures 1A and 1B present empirical semivariograms and normalized semivariograms, respectively, for sand, clay, $\mathrm{K}_{\mathrm{s}}, \mathrm{NO}_{3}-\mathrm{N} 2008$, and $\mathrm{pH}$ 2008. Table 1 presents the semivariogram parameters. For isotropic second order stationary processes, semivariance/sill=1-correlation, and the two graphs provide equivalent information. Because they are negatively related, correlograms with higher values represent more spatially structured processes while semivariogram with higher values corresponds to less spatially structured processes. The examination of the normalized semivariograms in Figure 1B shows that the semivariance reaches the sill (or the correlation, not shown, drops to almost zero) the quickest for $\mathrm{pH}, 2008$. However, separation distance at which correlation goes to zero follows the order $\mathrm{pH}(2008)<\mathrm{NO}_{3}-\mathrm{N}<$ clay < sand < $\mathrm{K}_{\mathrm{s}}$. Such a variation indicates increasing range of spatial dependence from $\mathrm{pH}$ to $\mathrm{K}_{\mathrm{s}}$. The range of spatial dependence increases from 86 for $\mathrm{pH}$ to $563 \mathrm{~m}$ for $\mathrm{K}_{\mathrm{s}}$ (Table 1). The range at which the correlogram goes to zero ranges from $24 \mathrm{~m}$ for particulate organic matter nitrogen (POM-N) to $486 \mathrm{~m}$ for mineral- associated nitrogen (MAN) (Table 2), from $30 \mathrm{~m}$ for EC to $495 \mathrm{~m}$ for silt (Table 3), from $93 \mathrm{~m}$ for AWC to 741 for field capacity (FC), and from $91 \mathrm{~m}$ for PR to $433 \mathrm{~m}$ for bulk density $\left(\rho_{\mathrm{b}}\right)$ (Table 5 ).

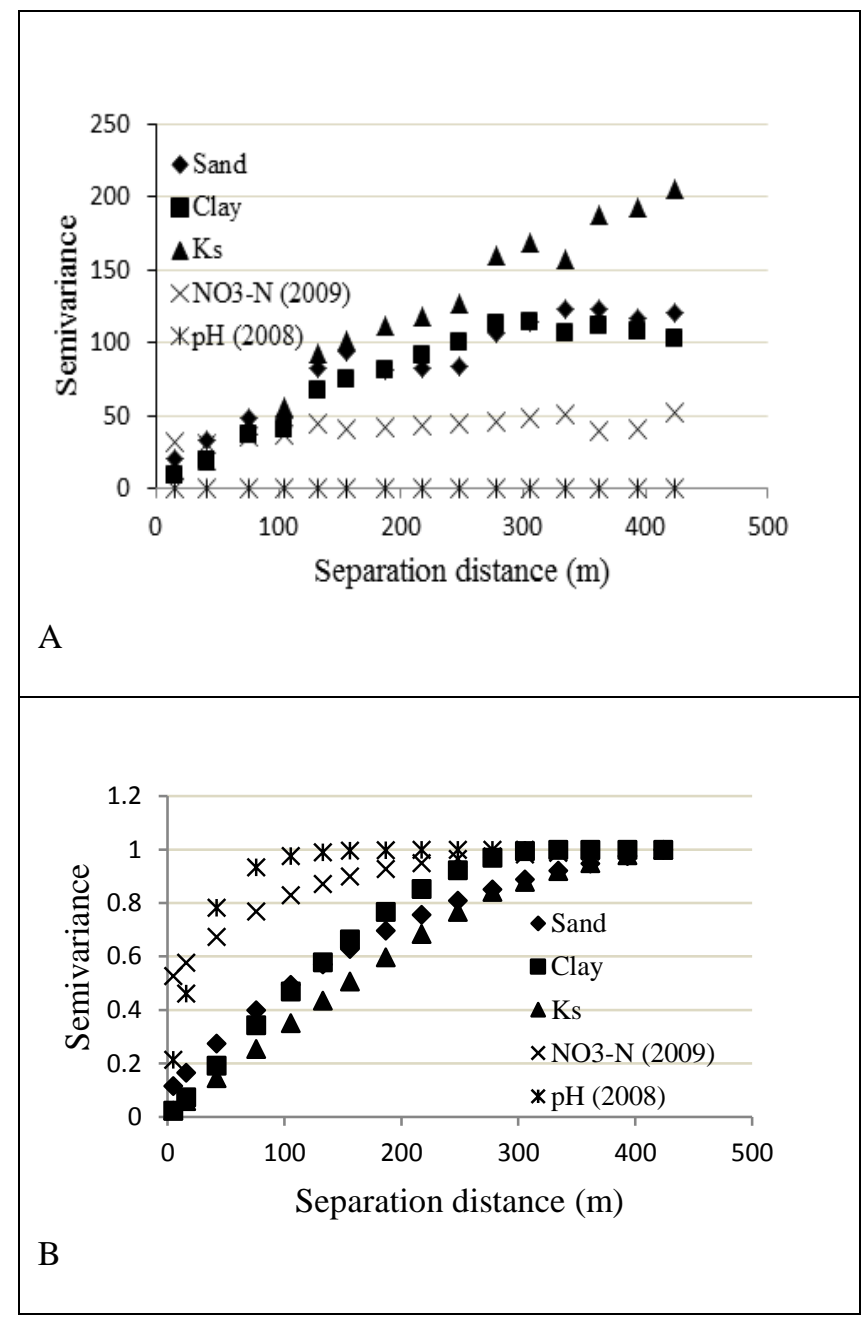

Figure 1 (A) Empirical semivariograms and (B) normalized semivariograms (semivariance/sill; normalized by fitted sill) for sand, clay, $\mathrm{Ks}, \mathrm{NO}_{3}-\mathrm{N}$ (2009), and pH (2008).

Table 1 Semivariogram model parameters of soil properties [14]. 


\begin{tabular}{|c|c|c|c|c|c|c|c|c|c|}
\hline$\dagger$ †ariable & Min & Max & \$Model & Nugget & Sill & $\begin{array}{l}\text { Range } \\
\text { M }\end{array}$ & $\$ N R$ & $\begin{array}{l}\text { J1 } \\
\text { m }\end{array}$ & $\begin{array}{l}\text { J2 } \\
\text { m }\end{array}$ \\
\hline Sand & 7.84 & $\begin{array}{l}69.8 \\
\end{array}$ & Exp. & $\begin{array}{l}18.4 \\
\end{array}$ & 121 & 410 & 0.15 & 116 & 178 \\
\hline Clay & 12.2 & 64.2 & Sph. & 0.1 & 109 & 325 & 0.00 & 122 & 145 \\
\hline$\rho_{\mathrm{b}}$ & 1.19 & 1.53 & Sph. & 0.00003 & 0.004 & 391 & 0.01 & 146 & 174 \\
\hline Ks & 3.36 & 76.1 & Sph. & 2.3 & 232 & 563 & 0.01 & 209 & 251 \\
\hline FC & 0.18 & 0.45 & Sph. & 1.91 & 33 & 355 & 0.06 & 125 & 254 \\
\hline WP & 0.10 & 0.37 & Sph. & 2.3 & 27 & 297 & 0.09 & 102 & 127 \\
\hline AWC & 0.05 & 0.19 & Exp. & 1.64 & 3.47 & 134 & 0.47 & 24 & 46 \\
\hline $\mathrm{pH}(2008)$ & 6.70 & 8.60 & Exp. & 0.006 & 0.086 & 86 & 0.07 & 27 & 39 \\
\hline $\mathrm{pH}(2009)$ & 6.40 & 8.50 & Exp. & 0.002 & 0.088 & 89 & 0.02 & 29 & 41 \\
\hline EC (2008) & 0.11 & 1.59 & Exp. & 0.013 & 0.122 & 95 & 0.11 & 28 & 42 \\
\hline EC (2009) & 0.12 & 1.39 & Exp. & 0.038 & 0.077 & 170 & 0.49 & 29 & 57 \\
\hline $\mathrm{Cl}(2008)$ & 0.40 & 106 & Exp. & 22.4 & 437 & 164 & 0.05 & 52 & 75 \\
\hline $\mathrm{Cl}(2009)$ & 2.40 & 79.8 & Exp. & 33.5 & 341 & 178 & 0.10 & 54 & 80 \\
\hline $\begin{array}{l}\mathrm{NO}_{3}-\mathrm{N} \\
(2008)\end{array}$ & 0.01 & 38.0 & Exp. & 17.2 & 56 & 215 & 0.31 & 50 & 84 \\
\hline $\begin{array}{l}\mathrm{NO}_{3}-\mathrm{N} \\
(2009) \\
\end{array}$ & 1.00 & 39.0 & Exp. & 23.6 & 47 & 303 & 0.50 & 50 & 101 \\
\hline
\end{tabular}

$\uparrow \rho_{\mathrm{b}}=$ bulk density; $K \mathrm{~s}=$ saturated hydraulic conductivity; $\mathrm{FC}=$ field capacity, volumetric water content at $-33 \mathrm{kPa}$; WP $=$ wilting point, volumetric water content at $-1500 \mathrm{kPa}$; AWC $=$ available water content, calculated as the difference between -33 , and $-1500 \mathrm{kPa} ; \mathrm{EC}=$ electrical conductivity $\left(\mathrm{dS} \mathrm{m} \mathrm{m}^{-1}\right)$; $\mathrm{NO}_{3}-\mathrm{N}=$ nitrate- $\mathrm{N}\left(\mathrm{mg} \mathrm{kg}^{-1}\right) ; \mathrm{Cl}=$ chloride $\left(\mathrm{mg} \mathrm{kg}^{-1}\right)$. $\S$ Sph. $=$ spherical; Exp. $=$ exponential. $\$ N R=$ nugget semivariance/sill.

\section{Impact of Semivariogram Model on Spatial Dependence}

Tables 1-5 presents the variogram model parameters for the data used from various studies. In order to evaluate the impact of the semivariogram model on spatial dependence, we have selected the sand and clay data from [14] because this data-set and variogram analysis are available to us. A set of exponential and spherical semivariogram models for sand and clay content, respectively were fitted to the experimental semivariogram (Table 1). Both experimental semivariograms were divided by their respective fitted sills to obtain a normalized semivariogram with a sill value of one and a range of nearly $400 \mathrm{~m}$ (Figure 2A). figure $2 \mathrm{~B}$ shows the corresponding empirical correlation functions (or correlograms) for both sand and clay. The normalized semivariograms and empirical correlation functions of WP and $\mathrm{NO}_{3}-\mathrm{N}, 2009$ are presented in Figures $3 \mathrm{~A} \& \mathrm{~B}$. Both empirical semivariograms in Fig. 3A have a sill value of one and a range of nearly $300 \mathrm{~m}$.
It is known that semivariograms exhibiting a more gradual increase near the origin correspond to smoother and more continuous processes ([19], [26]. Processes are smoother because they have higher correlations [26], and the correlogram of a smoother process drops more slowly from its value of one. Figures $2 \mathrm{~A} \& \mathrm{~B}$ and Figures $3 \mathrm{~A} \& \mathrm{~B}$ indicated that the spherical model corresponded to a smoother process than the exponential model. The correlation is not uniformly higher at each equal range pair for the spherical model, but it is higher for smaller values of separation distance, and drops more slowly from a correlation of one at the origin (Figure 2B and 3B). More spatial structure is implied by the spherical model because the correlogram dropped more slowly from a value of one with increasing separation distance.

Table 2 Semivariogram model parameters of soil properties [17]. 


\begin{tabular}{|l|l|l|l|l|l|l|l|}
\hline$\dagger$ Variable & $\S$ SModel & Nugget & Sill & $\begin{array}{l}\text { Range } \\
\mathbf{m}\end{array}$ & $\mathbf{\$ N R}$ & $\begin{array}{l}\text { J1 } \\
\mathbf{m}\end{array}$ & $\begin{array}{l}\text { J2 } \\
\mathbf{m}\end{array}$ \\
\hline OC & Sph. & 0.0001 & 0.102 & 104 & 0.00 & 39 & 46 \\
\hline TN & Sph. & 0.0001 & 0.089 & 89 & 0.00 & 33 & 40 \\
\hline MAC & Sph. & 0.007 & 0.108 & 110 & 0.06 & 39 & 48 \\
\hline MAN & Sph. & 0.038 & 0.048 & 486 & 0.79 & 38 & 99 \\
\hline POM C & Sph. & 0.175 & 0.362 & 118 & 0.48 & 23 & 38 \\
\hline POM N & Sph. & 0.047 & 0.135 & 24 & 0.35 & 6 & 9 \\
\hline MBC & Sph. & 0.048 & 0.153 & 46 & 0.31 & 12 & 17 \\
\hline MBN & Sph. & 0.103 & 0.198 & 30 & 0.52 & 5 & 9 \\
\hline ERG & Sph. & 0.029 & 0.0324 & 270 & 0.90 & 11 & 39 \\
\hline MBP & Sph. & 0.029 & 0.127 & 70 & 0.23 & 20 & 27 \\
\hline Respiration & Sph. & 0.066 & 0.391 & 68 & 0.17 & 21 & 28 \\
\hline Kt & Sph. & 0.004 & 0.216 & 87 & 0.02 & 32 & 39 \\
\hline KOC & Sph. & 0.02 & 0.075 & 71 & 0.27 & 20 & 27 \\
\hline NO ${ }_{3}$-N & Sph. & 0.208 & 0.263 & 201 & 0.79 & 16 & 41 \\
\hline Min N & Sph. & 68.6 & 119.5 & 38 & 0.57 & 6 & 11 \\
\hline Bray's P & Sph. & 23.4 & 134.7 & 71 & 0.17 & 22 & 29 \\
\hline$\rho_{b}$ & Sph. & 0.0132 & 0.0356 & 129 & 0.37 & 30 & 46 \\
\hline pH & Sph. & 0.062 & 0.76 & 117 & 0.08 & 40 & 50 \\
\hline Macroaggregation & Sph. & 6.9 & 77.4 & 77 & 0.09 & 26 & 33 \\
\hline
\end{tabular}

$\dagger \mathrm{OC}=$ total organic carbon; $\mathrm{TN}=$ total nitrogen; MAC and MAN = mineral-associated, $($ silt + clay $)$ carbon and nitrogen; Min $\mathrm{N}=$ mineralizable $\mathrm{N}$; $\mathrm{POM}$ $\mathrm{C}$ and POM $\mathrm{N}=$ participate organic matter carbon and nitrogen; $\mathrm{MBC}$ and $\mathrm{MBN}=$ microbial biomass carbon and nitrogen; ERG = ergosterol; $\mathrm{MBP}=$ microbial lipid $\mathrm{P} ; K t=$ sorption coefficient (atrazine); $\mathrm{KOC}=K t \bullet * \bullet \% \mathrm{OC} ; \rho_{\mathrm{b}}=$ bulk density.

$\S$ Sph. $=$ spherical.

$\$ N R=$ nugget semivariance/sill.

\section{Impact of the Range on Spatial Dependence}

In order to evaluate the impact of range on the spatial dependence of soil properties, the $\mathrm{NO}_{3}-\mathrm{N}, 2009$ and EC, 2008 were selected (Table 1). An exponential model determined the best fit to the semivariograms of both $\mathrm{NO}_{3}-\mathrm{N}, 2009$ and $\mathrm{EC}, 2008$. For the $\mathrm{NO}_{3}-\mathrm{N}$, 2009 semivariogram, range was $303 \mathrm{~m}$, a sill was 47, and a nugget was 23.6. For EC, 2008, estimated range was $95 \mathrm{~m}$, a sill was 0.122 , and the nugget was 0.013 (Table 1). According to the NR, $\mathrm{NO}_{3}-\mathrm{N}, 2009$ displayed moderate spatial dependence (NR of 0.50 ) while EC, 2008 displayed strong spatial dependence (NR of 0.11).
The empirical correlation function in Figure 4 indicates that correlations were higher for $\mathrm{NO}_{3}-\mathrm{N}$, 2009 than EC, 2008 at all the corresponding lag distances except at $16 \mathrm{~m}$ where correlations were high for EC, 2008. Correlations implied by the EC, 2008 semivariogram model were negligible at a lag distance of $155 \mathrm{~m}$ but at the same lag; the correlations for $\mathrm{NO}_{3}-\mathrm{N}, 2009$ were around 0.18 . While the large $\mathrm{NR}$ for $\mathrm{NO}_{3}-\mathrm{N}, 2009$ suggested moderate spatial dependence, due to the large range, the correlations decreased slowly from the ceiling provided by (1-NR). Thus EC, 2008 measurements could be considered as spatially independent at a separation distance of $155 \mathrm{~m}$, the $\mathrm{NO}_{3}-\mathrm{N}, 2009$ measurements could not be considered independent at $155 \mathrm{~m}$. Therefore, spatial dependence based on the NR method seemed inadequate to classify spatial dependence as $\mathrm{NO}_{3}-\mathrm{N}, 2009$ measurements remain spatially correlated for a longer separation distance than EC, 2008 measurements. The correlations for smallest lag distances will be important for mapping exercise, and the entire empirical correlation function will be useful for collecting future independent samples. 


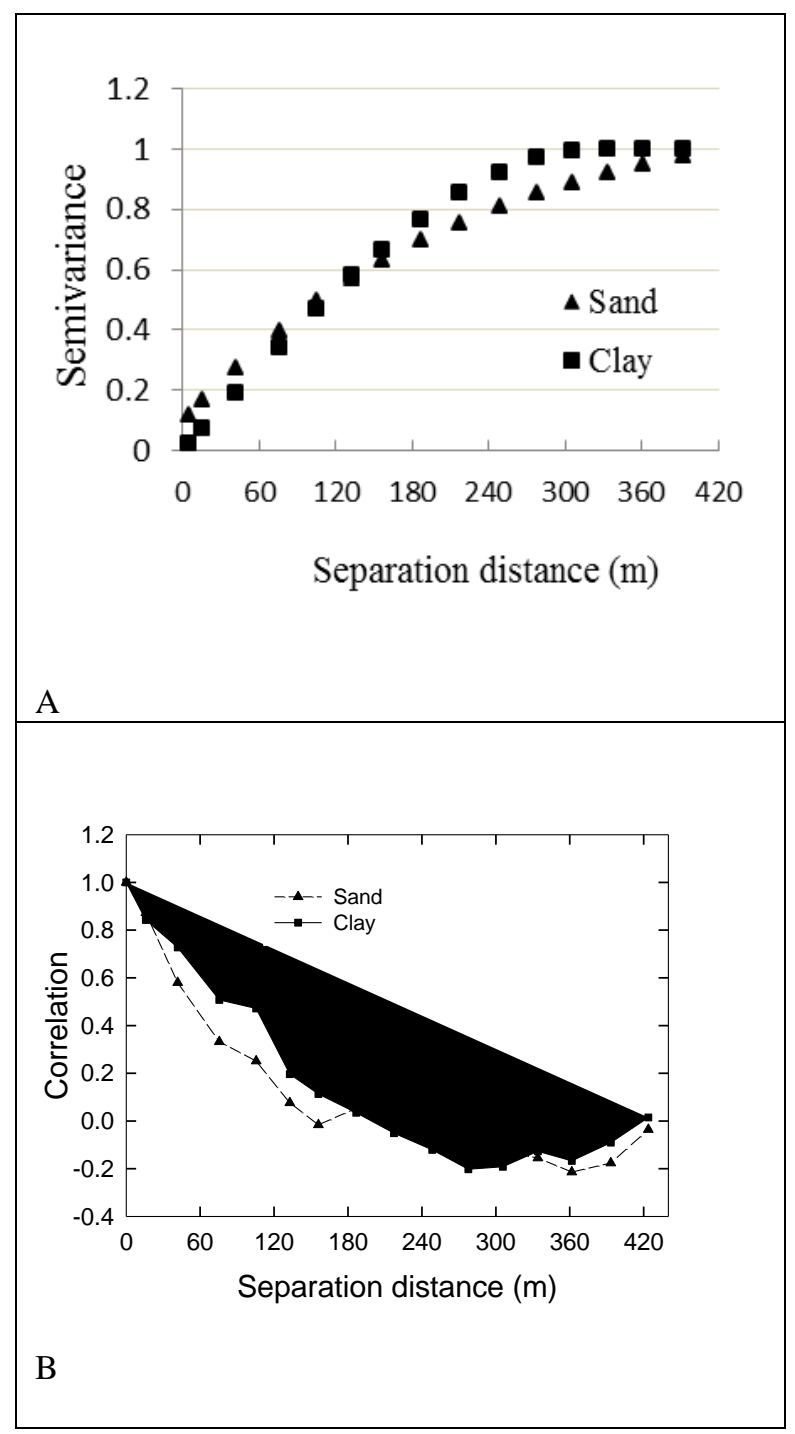

Figure 2. Normalized semivariogram (normalized by fitted sill) functions (A) and empirical correlation functions (B) of sand and clay content for exponential and spherical semivariograms, respectively.
Table 3 Semivariogram model parameters of soil properties [11].

\begin{tabular}{|c|c|c|c|c|c|c|c|}
\hline $\begin{array}{l}\dagger \text { Vari } \\
\text { able }\end{array}$ & $\begin{array}{l}\text { Mod } \\
\text { el }\end{array}$ & $\begin{array}{l}\text { Nug } \\
\text { get }\end{array}$ & Sill & $\begin{array}{l}\text { Ra } \\
\text { nge } \\
\text { m }\end{array}$ & $\begin{array}{l}+\dot{+} \\
\mathbf{N} \\
\mathbf{R}\end{array}$ & $\begin{array}{l}\mathbf{J} \\
\mathbf{1} \\
\mathbf{m} \\
\end{array}$ & $\begin{array}{l}\mathbf{J} \\
2 \\
\mathbf{m} \\
\end{array}$ \\
\hline Silt & $\begin{array}{l}\text { Sphe } \\
\text { rical }\end{array}$ & $\begin{array}{l}12.0 \\
8 \\
\end{array}$ & $\begin{array}{l}31 . \\
76\end{array}$ & 495 & $\begin{array}{l}0 . \\
38\end{array}$ & $\begin{array}{l}1 \\
1 \\
5 \\
\end{array}$ & $\begin{array}{l}1 \\
7 \\
4 \\
\end{array}$ \\
\hline Clay & $\begin{array}{l}\text { Sphe } \\
\text { rical }\end{array}$ & 5.24 & $\begin{array}{l}9.5 \\
1\end{array}$ & 347 & $\begin{array}{l}0 . \\
55\end{array}$ & $\begin{array}{l}5 \\
8\end{array}$ & $\begin{array}{l}1 \\
0 \\
4\end{array}$ \\
\hline$\rho_{b}$ & $\begin{array}{l}\text { Sphe } \\
\text { rical }\end{array}$ & 0.01 & $\begin{array}{l}0.0 \\
2 \\
\end{array}$ & 131 & $\begin{array}{l}0 . \\
50\end{array}$ & $\begin{array}{l}2 \\
5 \\
\end{array}$ & $\begin{array}{l}4 \\
1 \\
\end{array}$ \\
\hline $\mathrm{Ks}$ & $\begin{array}{l}\text { Sphe } \\
\text { rical }\end{array}$ & 0.06 & $\begin{array}{l}0.1 \\
1\end{array}$ & 154 & $\begin{array}{l}0 . \\
55\end{array}$ & $\begin{array}{l}2 \\
6\end{array}$ & $\begin{array}{l}4 \\
6\end{array}$ \\
\hline $\mathrm{pH}$ & $\begin{array}{l}\text { Sphe } \\
\text { rical }\end{array}$ & 0.01 & $\begin{array}{l}0.0 \\
109\end{array}$ & 158 & $\begin{array}{l}0 . \\
92\end{array}$ & 5 & $\begin{array}{l}2 \\
0\end{array}$ \\
\hline $\mathrm{EC}$ & $\begin{array}{l}\text { Sphe } \\
\text { rical }\end{array}$ & 0.01 & $\begin{array}{l}0.0 \\
2\end{array}$ & 30 & $\begin{array}{l}0 . \\
50\end{array}$ & 6 & 9 \\
\hline $\mathrm{TC}$ & $\begin{array}{l}\text { Sphe } \\
\text { rical }\end{array}$ & 0.04 & $\begin{array}{l}0.0 \\
7 \\
\end{array}$ & 163 & $\begin{array}{l}0 . \\
57\end{array}$ & $\begin{array}{l}2 \\
6 \\
\end{array}$ & $\begin{array}{l}4 \\
8 \\
\end{array}$ \\
\hline SOC & $\begin{array}{l}\text { Sphe } \\
\text { rical }\end{array}$ & 8.68 & $\begin{array}{l}16 . \\
64\end{array}$ & 184 & $\begin{array}{l}0 . \\
52 \\
\end{array}$ & $\begin{array}{l}3 \\
3 \\
\end{array}$ & $\begin{array}{l}5 \\
7 \\
\end{array}$ \\
\hline TN & $\begin{array}{l}\text { Sphe } \\
\text { rical }\end{array}$ & 0.47 & $\begin{array}{l}0.6 \\
1\end{array}$ & $\begin{array}{l}243 \\
.6\end{array}$ & $\begin{array}{l}0 . \\
77\end{array}$ & $\begin{array}{l}2 \\
1\end{array}$ & $\begin{array}{l}5 \\
2\end{array}$ \\
\hline
\end{tabular}

$\uparrow \rho_{\mathrm{b}}=$ bulk density; $K \mathrm{~s}=$ saturated hydraulic conductivity; $\mathrm{EC}=$ electrical conductivity; $\mathrm{TC}=$ organic carbon concentration; $\mathrm{SOC}=$ soil organic carbon; $\mathrm{TN}=$ soil nitrogen.

\$NR = nugget semivariance/sill. 


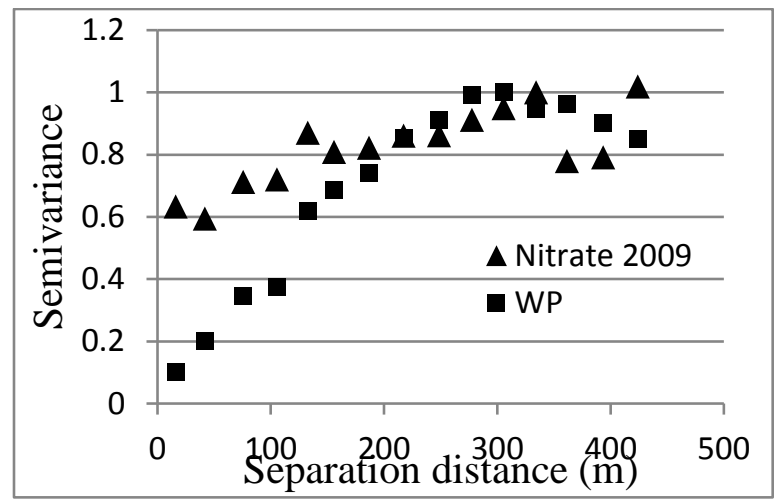

A

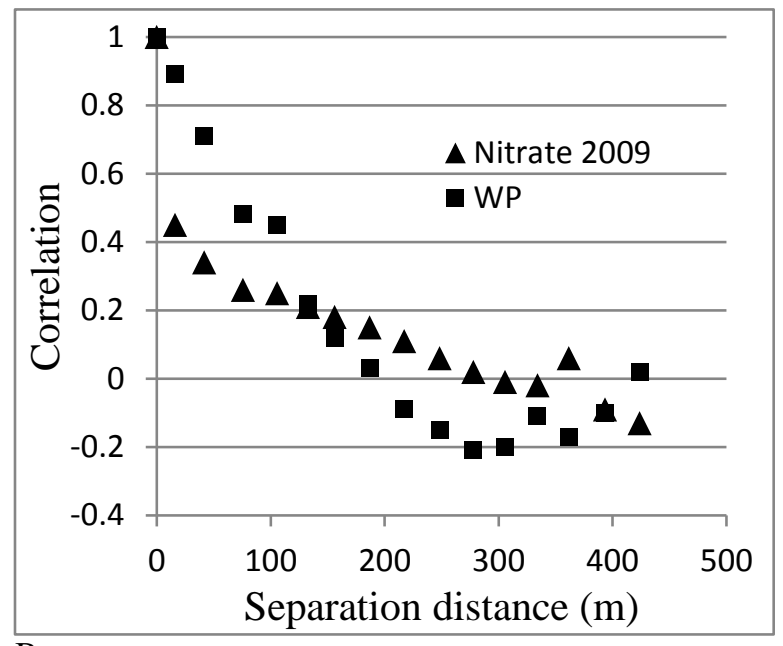

B

Figure 3. Empirical normalized semivariogram (normalized by fitted sill) functions (A) and empirical correlation functions (B) of nitrate-N 2009 and wilting point (WP) for exponential and spherical semivariograms, respectively.

Table 4 Semivariogram model parameters of soil properties [28].

\begin{tabular}{|c|c|c|c|c|c|c|c|}
\hline $\begin{array}{l}\dagger \text { Vari } \\
\text { able }\end{array}$ & Model & $\begin{array}{l}\text { Nug } \\
\text { get }\end{array}$ & $\begin{array}{l}\text { Sil } \\
\text { l }\end{array}$ & $\begin{array}{l}\text { Ra } \\
\text { nge } \\
\text { m }\end{array}$ & $\begin{array}{l}+ \\
\mathbf{N} \\
\mathbf{R}\end{array}$ & $\begin{array}{l}\mathbf{J} \\
\mathbf{1} \\
\mathbf{m}\end{array}$ & $\begin{array}{l}\mathbf{J} \\
2 \\
\mathbf{m}\end{array}$ \\
\hline$\rho_{b}$ & $\begin{array}{l}\text { Expon } \\
\text { ential }\end{array}$ & $\begin{array}{l}0.00 \\
2 \\
\end{array}$ & $\begin{array}{l}0.0 \\
07 \\
\end{array}$ & 106 & $\begin{array}{l}0 . \\
29 \\
\end{array}$ & $\begin{array}{l}2 \\
5 \\
\end{array}$ & $\begin{array}{l}4 \\
2 \\
\end{array}$ \\
\hline $\mathrm{Ks}$ & $\begin{array}{l}\text { Expon } \\
\text { ential }\end{array}$ & 0.46 & $\begin{array}{l}1.5 \\
06\end{array}$ & 94 & $\begin{array}{l}0 . \\
31\end{array}$ & $\begin{array}{l}2 \\
2\end{array}$ & $\begin{array}{l}3 \\
7\end{array}$ \\
\hline Sand & $\begin{array}{l}\text { Expon } \\
\text { ential }\end{array}$ & 78 & $\begin{array}{l}42 \\
7 \\
\end{array}$ & 421 & $\begin{array}{l}0 . \\
18\end{array}$ & $\begin{array}{l}1 \\
1 \\
5 \\
\end{array}$ & $\begin{array}{l}1 \\
7 \\
9 \\
\end{array}$ \\
\hline Clay & $\begin{array}{l}\text { Expon } \\
\text { ential }\end{array}$ & 16 & 65 & 218 & $\begin{array}{l}0 . \\
25\end{array}$ & $\begin{array}{l}5 \\
5\end{array}$ & $\begin{array}{l}8 \\
9\end{array}$ \\
\hline $\mathrm{FC}$ & $\begin{array}{l}\text { Spheri } \\
\text { cal }\end{array}$ & 16 & 60 & 741 & $\begin{array}{l}0 . \\
27\end{array}$ & $\begin{array}{l}2 \\
0 \\
4\end{array}$ & $\begin{array}{l}2 \\
8 \\
4\end{array}$ \\
\hline WP & $\begin{array}{l}\text { Spheri } \\
\text { cal }\end{array}$ & 12 & 70 & 425 & $\begin{array}{l}0 . \\
17\end{array}$ & $\begin{array}{l}1 \\
3 \\
2 \\
\end{array}$ & $\begin{array}{l}1 \\
7 \\
3\end{array}$ \\
\hline AWC & $\begin{array}{l}\text { Expon } \\
\text { ential }\end{array}$ & 4 & 12 & 93 & $\begin{array}{l}0 . \\
33\end{array}$ & $\begin{array}{l}2 \\
1\end{array}$ & $\begin{array}{l}3 \\
6\end{array}$ \\
\hline
\end{tabular}

$\dagger \rho_{\mathrm{b}}=$ bulk density; $K \mathrm{~s}=$ saturated hydraulic conductivity; $\mathrm{FC}$ = field capacity, volumetric water content at $-33 \mathrm{kPa}$; WP $=$ wilting point, volumetric water content at $-1500 \mathrm{kPa}$; AWC = available water content, calculated as the difference between -33 , and $-1500 \mathrm{kPa}$.

$\$ N R=$ nugget semivariance/sill.

Similarly, we can consider an example from Table 2 [17] to further explore the role of range in spatial dependence profile. We select MAN and particulate organic matter nitrogen (POM-N) variograms from [17]. A spherical model was the best-fit for the variable MAN [17]. The model produced a range of $486 \mathrm{~m}$, sill of 0.048 and nugget of 0.038 . The NR was 0.79 suggesting that the MAN displayed weak spatial dependence. A spherical model was the bestfit for POM-N with a range of $24 \mathrm{~m}$, a sill of 0.135 and a nugget of 0.047 . The NR was 0.35 suggesting that the POM-N is moderately spatially dependent (Table 2). As the range is larger for MAN and autocorrelations are greater than for POM-N at most separation distances, consequently, it is arguable that MAN could have greater spatial structure than POM$\mathrm{N}$. 
Table 5 Semivariogram model parameters of soil properties [12].

\begin{tabular}{|c|c|c|c|c|c|c|c|}
\hline $\begin{array}{l}\text { †Var } \\
\text { iable }\end{array}$ & $\begin{array}{l}\text { Mode } \\
1\end{array}$ & $\begin{array}{l}\text { Nug } \\
\text { get }\end{array}$ & Sill & $\begin{array}{l}\text { Ra } \\
\text { nge } \\
\text { m }\end{array}$ & $\begin{array}{l}+ \\
\mathbf{N} \\
\mathbf{R}\end{array}$ & $\begin{array}{l}\mathbf{J} \\
\mathbf{1} \\
\mathbf{m}\end{array}$ & $\mathbf{J}$ \\
\hline Clay & & 12.5 & $\begin{array}{l}102 . \\
6 \\
\end{array}$ & 379 & $\begin{array}{l}0 . \\
12 \\
\end{array}$ & $\begin{array}{l}1 \\
2 \\
5 \\
\end{array}$ & 9 \\
\hline Silt & & 92 & $\begin{array}{l}14.3 \\
7 \\
\end{array}$ & 297 & $\begin{array}{l}0 . \\
48 \\
\end{array}$ & $\begin{array}{l}5 \\
1 \\
\end{array}$ & $\begin{array}{l}0 \\
1\end{array}$ \\
\hline Sand & & 0 & $\begin{array}{l}0.10 \\
5\end{array}$ & 372 & $\begin{array}{l}0 . \\
62\end{array}$ & $\begin{array}{l}5 \\
3\end{array}$ & 3 \\
\hline GWC & ri & 7.73 & $\begin{array}{l}27.2 \\
4\end{array}$ & 384 & $\begin{array}{l}0 . \\
28\end{array}$ & $\begin{array}{l}1 \\
0 \\
3\end{array}$ & $\begin{array}{l}1 \\
4 \\
5\end{array}$ \\
\hline$\rho_{b}$ & heri & $\begin{array}{l}0.00 \\
783\end{array}$ & $\begin{array}{l}0.01 \\
968\end{array}$ & 433 & $\begin{array}{l}0 . \\
40\end{array}$ & $\begin{array}{l}9 \\
8\end{array}$ & $\begin{array}{l}1 \\
5 \\
0\end{array}$ \\
\hline PR & $\begin{array}{l}\text { Spheri } \\
\text { cal }\end{array}$ & $\begin{array}{l}0.02 \\
84 \\
\end{array}$ & $\begin{array}{l}0.29 \\
38 \\
\end{array}$ & 91 & $\begin{array}{l}0 . \\
97 \\
\end{array}$ & 1 & 7 \\
\hline
\end{tabular}

†GWC = gravimetric water content; $\rho_{\mathrm{b}}=$ bulk density; $\mathrm{PR}=$ penetration resistance.

$\ddagger N R=$ nugget semivariance/sill.

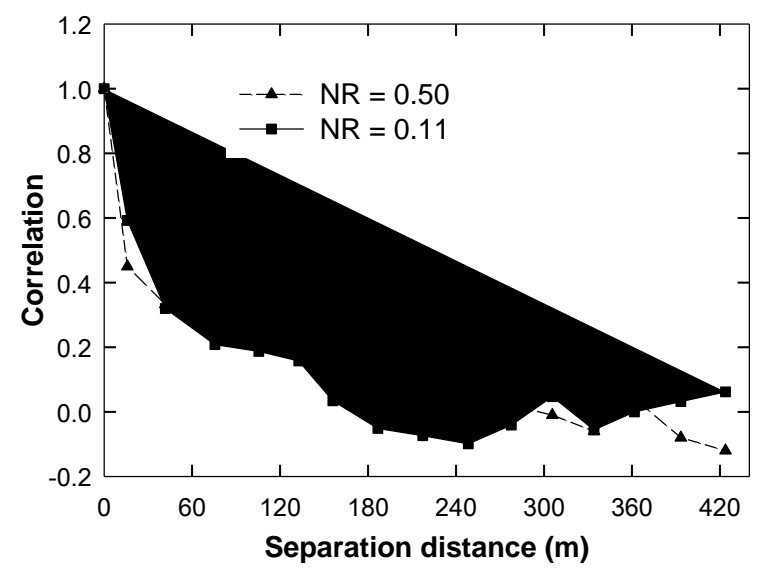

Figure 4. Empirical correlation functions for $\mathrm{NO}_{3}-\mathrm{N}$, $2009(\mathrm{NR}=0.50)$ and $\mathrm{EC}, 2008(\mathrm{NR}=0.11)$.

The empirical correlation function for $\mathrm{NO}_{3}-\mathrm{N}, 2008$ and $\mathrm{pH}, 2008$ presented in figure 5 shows that these two have large differences in the optimized range of spatial dependence. For $\mathrm{NO}_{3}-\mathrm{N}, 2008$, an exponential semivariogram was the best fit with a range of $215 \mathrm{~m}$, a sill of 56, and a nugget of 17.2. For $\mathrm{pH}, 2008$, exponential semivariogram was also the best fit with a range of $86 \mathrm{~m}$, a sill of 0.086 , and a nugget of 0.006 . The $\mathrm{NR}$ was 0.31 for $\mathrm{NO}_{3}-\mathrm{N}$ indicating moderate spatial dependence; while the NR for pH, 2008 was 0.07 exhibiting strong spatial dependence (Table 1). At a lag distance of $16 \mathrm{~m}$, the autocorrelation implied by the exponential semivariogram was 0.41 for $\mathrm{NO}_{3}-\mathrm{N}, 2008$ and 0.69 for $\mathrm{pH}, 2008$. But at all other lag distances, the correlations for $\mathrm{NO}_{3}-\mathrm{N}, 2008$ were higher than $\mathrm{pH}$, 2008 until the correlations became negligible. At a lag distance of $76 \mathrm{~m}$, the autocorrelation for $\mathrm{pH}, 2008$ dropped to almost negligible while for $\mathrm{NO}_{3}-\mathrm{N}, 2008$ it was still 0.21 . The $\mathrm{NO}_{3}-\mathrm{N}, 2008$ exhibited positive autocorrelation even at a lag distance of $217 \mathrm{~m}$. Although $\mathrm{NO}_{3}-\mathrm{N}, \quad 2008$ showed higher autocorrelations at nearly all lag distances when compared with $\mathrm{pH}, 2008$ still according to NR classification $\mathrm{NO}_{3}-\mathrm{N}, 2008$ was classified as moderately spatially dependent whereas pH, 2008 as strongly spatially dependent. Consequently, it is arguable that $\mathrm{NO}_{3}-\mathrm{N}, 2008$ could have greater spatial structure than $\mathrm{pH}, 2008$.

So far the data showed that range has an important influence on characterizing spatial dependence. Now the question is if range alone could be enough to characterize spatial dependence? Figure 6 presents the correlograms for AWC and pH, 2008 (Table 1). For AWC, the range was $134 \mathrm{~m}$ and the NR was 0.47 ; for $\mathrm{pH}, 2008$ the range was $86 \mathrm{~m}$ and the NR was 0.07 . Based on the ranges, one would expect the spatial dependence profile of the AWC to reflect the greater spatial structure than $\mathrm{pH}, 2008$. But figure 6 shows that autocorrelations are higher for $\mathrm{pH}, 2008$ than AWC and thus, $\mathrm{pH}, 2008$ exhibits greater spatial structure than AWC. Thus, for these two spatial processes, the difference in the NR values has a greater impact on the spatial dependence profile than the difference in the ranges for nearly all lag distances. While the NR contains information about the degree of spatial structure, so does the range and to a lesser extent, the semivariogram model form. In some instances, particularly when the ranges of compared processes are vastly different, spatial dependence profiles may reflect differences in the ranges more than differences in NR values. On the other hand, spatial dependence profiles may reflect differences in NR values more than differences in the range. 


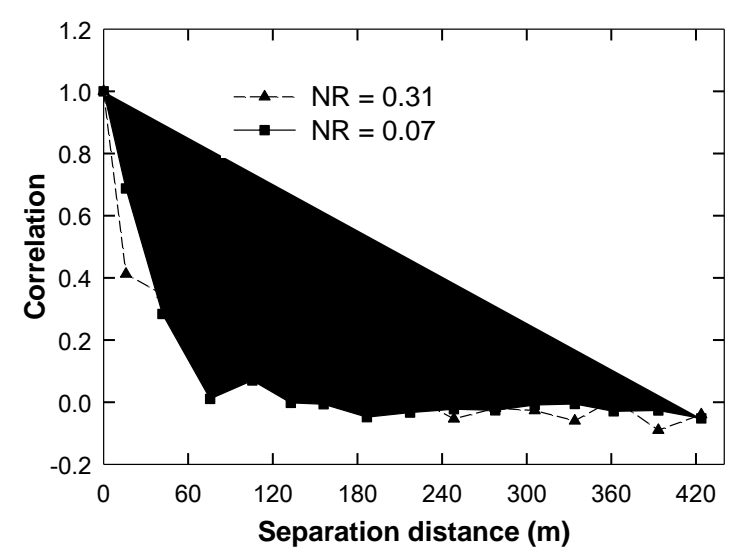

Figure 5. Empirical correlation functions for $\mathrm{NO}_{3}-\mathrm{N}$, $2008(\mathrm{NR}=0.31)$ and $\mathrm{pH}, 2008(\mathrm{NR}=0.07)$

In many cases, spatial dependence profiles may not uniformly reflect differences in either the range or the $\mathrm{NR}$; rather spatial dependence profiles may compare differently at different intervals of lag values. Because, for lag distance $>0,(1-\mathrm{NR})$ is the upper bound on the correlation and serves as a multiplicative factor on the correlations and spatial dependence profile, (1-NR) scales the entire correlogram down. But the range and the semivariogram model form determine how quickly correlations drop from (1-NR).

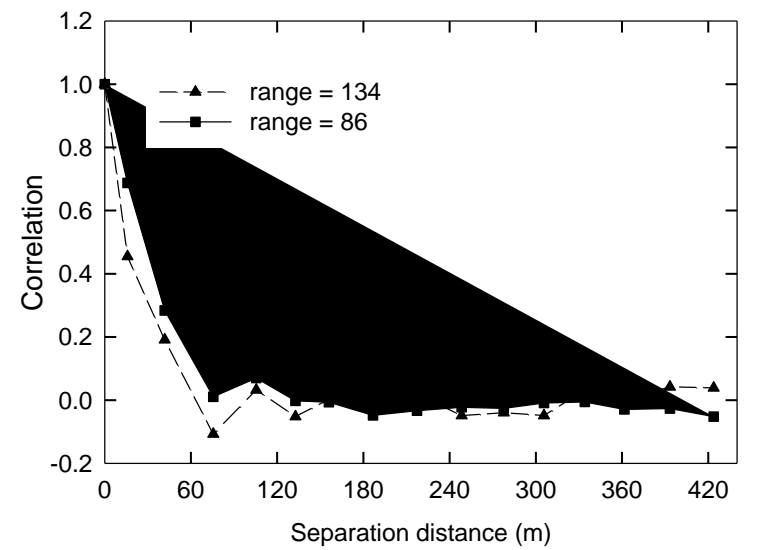

Figure 6. Empirical correlation functions for AWC (range $=134 \mathrm{~m} ; \mathrm{NR}=0.47)$ and $\mathrm{pH}, 2008($ range $=86$ $\mathrm{m} ; \mathrm{NR}=0.07)$.

\section{Integral Scales}

The nugget ratio classified all the soil physical properties in Table 1 as strongly spatially dependent except AWC. Examination of soil $\mathrm{pH}$ with a low variability from 6.5 to 8 during the two years (Table 1) indicated that according to $\mathrm{NR}, \mathrm{pH}$ both years displayed strong spatially dependent, in contrast small integral scale values because of small range displayed weak spatially dependent. Similarly, NR classified soil EC as strong spatially dependent in contrast small integral scale values indicate low to moderate spatially dependent during both years. As far as chloride is concerned, integral scale values were small describing them as weak spatially dependent whereas NR classified them as strong spatially dependent. Overall, both models showed disagreement in classifying the spatial dependence of most of the measured parameters.

A closer examination of the correlogram displayed in figure 3 indicated that the spatial dependence profiles were more consistent using integral scales. Similar conclusions can be drawn for $\mathrm{NO}_{3}-\mathrm{N}$ (Fig. 4). Table 2 also showed disagreement between the two approaches in classifying the spatial dependence of the parameters. The NR model classified all the parameters in Table 2 from weak to strong spatially dependent, in contrast, integral scale values were low indicating that the spatial dependence of the parameters was weak.

EC was moderate spatially dependent $(\mathrm{NR}=0.50)$ whereas soil nitrogen $(\mathrm{TN})$ weak spatially dependent $(\mathrm{NR}=0.77)$ [11], Table 3). The integral scale values of $\mathrm{J} 1$ were $6 \mathrm{~m}$ and $21 \mathrm{~m}$ for $\mathrm{EC}$ and TN, respectively and estimated $\mathrm{J} 2$ values were $9 \mathrm{~m}$ and $52 \mathrm{~m}$, respectively. Again, the integral scales provide a very different picture of degrees of spatial dependence than the NR.

Reference [28] also used NR classification to categorize the spatial dependence as strong, moderate and weak. According to NR classification, sand displayed strong spatial dependence $(\mathrm{NR}=0.18)$ and field capacity (FC) moderate spatial dependence $(\mathrm{NR}=0.27)$. The estimated $\mathrm{J} 1$ values were $115 \mathrm{~m}$ and $204 \mathrm{~m}$ for sand and FC, respectively while estimated J2 values were $179 \mathrm{~m}$ and $204 \mathrm{~m}$, respectively. Therefore, FC classified as moderate spatially dependent by NR had higher integral scale values than sand classified as strong spatially dependent by NR.

The classification of spatial dependence showed a disagreement between NR and integral scales for some soil variables; it showed an agreement for several other soil variables. For example, Table 5 showed a consistency between NR and integral scale values (J1 and $\mathrm{J} 2$ ) for soil variables where with an increase in the NR values, $\mathrm{J} 1$, and $\mathrm{J} 2$ values decreased correspondingly and vice versa. Thus, methods seem to be suited to comparing spatial dependence of different processes but not for classifying the spatial dependence as strong, moderate, or weak. Integral scales are useful when a single number summary is required for expressing the spatial dependence of soil properties. This is not 
available with correlograms or normalized variograms. Integral scales include the range of spatial dependence and therefore replace correlograms or normalized semivariograms. However, when the purpose is to identify processes that remain highly correlated for a longer lag distances, use of correlogram seems a good option.

The NR classification appeals to researchers attempting to summarize and compare the results of many spatial analyses. However,not enough information is available for mapping or future sampling design. Because the range has a strong effect on the spatial dependence profile, it is difficult to define an appropriate quantity that might be used to create a classification of spatial dependence strength that can be applied uniformly regardless of the context. Such classifications tend to be based on unitless quantities or percent or proportion scales, but both the range and integral scales are in the units of measured distances; there is no upper bound on the value these quantities can assume. Researchers who want to define spatial dependence categories using integral scales may have to come up with definitions that make sense in the context of their discipline. Either of the integral scales might be the basis for such a classification.

Alternatively, spatial dependence classifications might also be defined based on correlations at specified distances. While classifications exist for correlations [35], information is not available on a meaningful distance to base the classification by the soil property and the study region. This classification can be based on the objectives of the analysis, for example, using higher correlations and closer lag distances for preparing contiguous maps. While using lower correlations or beyond the lag distance at which correlations are no longer significant for collecting independent samples. Correlograms for various soil properties can be plotted together for the ease of designing a future sampling strategy. Furthermore, information on spatial dependence of soil attributes may be used within a research context or to apply precision farming practices. In a research context, knowing distances within which correlations are high or low might facilitate establishing blocks or might allow the researcher to know when experimental units are far enough apart that correlations are negligible. When attempting to apply precision farming, sampling at intervals close enough can allow creating an accurate map of the entire field; again, knowing distances at which correlations are high or moderate might facilitate arriving at standardized sampling schemes. Consequently, another approach to characterizing spatial dependence might be to indicate whether correlations are high, moderate or weak at either a particular lag interval or at regular lag intervals such as $\mathrm{h}=15 \mathrm{~m}, 30 \mathrm{~m}$, etc. As an example, [35] suggested a scheme for classifying correlations with magnitudes less than 0.5 as weak, between 0.5 and 0.8 as moderate and above 0.8 as strong. The lower bound of the classification based on correlations could be where it is no longer significant at $5 \%$ probability level.

\section{CONCLUSIONS}

Comparing spatial dependence of isotropic second order stationary processes by the semivariogram is complicated by the fact that the semivariogram contains information about both the variability and spatial dependence of the compared processes. The semivariogram form, the range, and the NR contribute to the implied spatial dependence profile and further complicate the comparison. However, dividing the semivariogram by the sill to obtain a normalized semivariogram creates a unitless spatial dependence profile that can be used to graphically compare spatial structures of different processes. Similarly, the correlogram, which is negatively related to the normalized semivariogram, also can be used to create graphs of spatial dependence profiles. Both can be easily used for the purpose of mapping as well as for designing a future sampling strategy involving collection of independent samples. Integral scales incorporate information from all three semivariogram model attributes - model form, range and NR - that inform the spatial dependence profile and can be used to obtain a single number summary of the spatial dependence. While two integral scale forms have appeared in the literature, either form provides a reasonable basis for comparing spatial structure. Both scales can easily be used to identify the properties with the greater spatial structure as well as could be a useful tool for future independent sample collection strategy.

\section{Acknowledgements}

Authors thank New Mexico State University Agricultural Experiment Station, Las Cruces, NM for the support. Thanks are also due to NIFA and Nakayama Chair. 


\section{REFERENCES}

[1] Gaston, L.A., Locke M.A., Zablotowicz R.M., and Reddy K.N. 2001. Spatial variability of soil properties and weed populations in the Mississippi Delta. Soil Sci. Soc. Am. J. 65:449-459.

[2] Haws, N.W., Liu B., Rao P.S.C., Kladivko E.J. and Franzmeier D.P. 2004. Spatial variability and measurement scale of infiltration rate on an agricultural landscape. Soil Sci. Soc. Am. J. 68:1818-1826.

[3] van Es, H.M., Ogden C.B., Hill R.L., Schindelbeck R.R., and Tsegaye T. 1999. Integrated assessment of space, time, and management-related variability of soil hydraulic properties. Soil Sci. Soc. Am. J. 63:1599-1608.

[4] Goovaerts, P. 1997. Geostatistics for natural resource evaluation. Oxford Univ. Press, New York.

[5] Sisson, J.B. and Wierenga P.J. 1981. Spatial variability of steady state infiltration rates as a stochastic process. Soil Sci. Soc. Am. Proc. 45:699-704.

[6] Regalado, C.M., and Ritter A. 2006. Geostatistical tools for characterizing the spatial variability of soil water repellency parameters in a laurel forest watershed. Soil Sci. Soc. Am. J. 70:1071-1081.

[7] Worsham, L., Markewitz, D. and Nibbelink N. 2010. Incorporating spatial dependence into estimates of soil carbon contents under different land covers. Soil Sci. Soc. Am. J. 74: 2: 635-646.

[8] Gajem, Y.M., Warrick A.W., and Meyers D.E. 1981. Spatial dependence of physical properties of a Typic torrifluvent soil. Soil Sci. Soc. Am. J. 45:709-715.

[9] Trangmar, B.B., Yost R.S., and Uehara G. 1987. Spatial variation of soil properties and rice yield on recently cleared land. Soil Sci. Soc. Am. J. 51:668-674.

[10] Ovalles, F.A., and Collins M.E. 1988. Evaluation of soil variability in northwest Florida using geostatistics. Soil Sci. Soc. Am. J. 52:1702-1708.

[11] Shukla, M.K., Slater B.K., Lal R., and Cepuder P. 2004. Spatial variability of soil properties and potential management classification of a chernozemic field in lower Australia. Soil Sci. 169: 852-860.

[12] Ozgoz, E. 2009. Long term conventional tillage effect on spatial variability of some soil physical properties. J. Sustainable Agric., 33: 142-160.

[13] Adhikari, P., M. K. Shukla, and J. G. Mexal. 2012. Spatial variability of infiltration rate and soil chemical properties of desert soils:

implications for management of irrigation using treated wastewater. Trans. of the ASABE 55(5): 1711-1721.

[14] Sharma P., Shukla M.K., and Mexal J G. 2011. Spatial Variability of soil properties in agricultural fields of southern New Mexico. Soil Science. 176(6):288-302.

[15] Russo, D. and Bresler E. 1981. Soil hydraulic properties as stochastic processes: I. an analysis of field spatial variability. Soil Sci. Soc. Am. J. 45:682-687.
[16] McBratney, A.B. and R. Webster, 1986. Choosing functions for semi-variograms of soil properties and fitting them to sampling estimates. J. Soil Sci. 37:617-639.

[17] Cambardella, C.A., Moorman T.B., Novak J.M., Parkin T.B., Karlan D.L., Turco R.F. and Konopka A.E. 1994. Field scale variability of soil properties in central Iowa soils. Soil Sci. Soc. Am. J. 58:1501-1511.

[18] Lark, R.M. and R. Webster. 2001. Changes in variance and correlation of soil properties with scale and location: analysis using an adapted maximal overlap discrete wavelet transform. European Journal of Soil Science 52, 547-562.

[19] Schabenberger, O., and Pierce F.J. 2002. Contemporary statistical models for the plant and soil science. p. 738. CRC Press, New York, NY.

[20] Isaaks, E. H., and Srivastava R. M.. 1989. An Introduction to Applied Geostatistics, Oxford University Press, New York, $561 \mathrm{pp}$.

[21] Walley, F., Fu G., van Groenigen J.and van Kessel C. 2001. Short-range spatial variability of nitrogen fixation by fieldgrown chickpea. Soil Sci. Soc. Am. J. 65:1717-1722.

[22] Katsvairo, T.W., Cox W. J., Van Es H. M., and Glos M. 2003. Spatial yield response of two corn hybrids at two nitrogen levels. Agron. J. 95:1012-1022.

[23] Shahandeh, H., Wright A. L., Hons F. M., and Lascano R. J. 2005. Spatial and temporal variation of soil nitrogen parameters related to soil texture and corn yield. Agron. J. 97:772-782.

[24] Duffera, M., White J. G. and Weisz R. 2007. Spatial variability of southeastern U.S. coastal plain soil physical properties: implications for site-specific management. Geoderma 137:327-339.

[25] Shukla M.K., Lal R., and VanLeeuwen D. 2007. Spatial variability of aggregate associated- carbon and nitrogen contents in the reclaimed minesoils of eastern Ohio. Soil Sci. Soc. Am. J. 71:1748-1757.

[26] Schabenberger, O. and Gotway C.A. 2005. Statistical methods for spatial data analysis. Chapman-Hall, CRC, New York, NY.

[27] Russo, D. and Jury W.A. 1987. A theoretical study of the estimation of the correlation scale in spatially-variable fields: 1:stationary fields. Water Resour. Res. 23:1257-1268.

[28] Iqbal, J., Thomasson J.A., Jenkins J.N., Owens P.R. and Whisler F.D. 2005. Spatial variability analysis of soil physical properties of alluvial soils. Soil Sci. Soc. Am. J. 69: 1338-1350.

[29] Bulloch, H. E. and Neher R. E. 1980. Soil survey of Dona Ana county area New Mexico. United States. Department of Agriculture, Soil Conservation service.

[30] Soil Survey Staff. 1999. Soil Taxonomy: A basic system of soil classification for making and interpreting soil surveys. 2nd ed. Agric. Handb. 436. U.S. Gov. Print. Office, Washington, DC.

[31] Trangmar, B.B., Yost R.S., and Uehara G. 1985. Application of geostatistics to spatial studies of soil properties. Adv. Agron.38: 45-94. 
[32] Yates, S.R. and AWarrick A. 2002. Geostatistics pp. 81-118. In J.H. Dane and G.C. Topp (eds.). Methods of soil analysis, Part 4- Physical methods. SSSA, Madison, WI.

[33] Lumley, J.L. and Panofsky A. 1964. The structure of atmospheric turbulence. John Wiley and Sons Inc. New York, NY.

[34] Solie, J.B., Raun W.R. and Stone M.L. 1999. Submeter spatial variability of selected soil and bermudagrass production variables. Soil Sci. Soc. Am. J. 63:1724-1733.

[35] Devore, J. and Peck R. 1986. Statistics: The Exploration and Analysis of Data. West Publishing Company, St. Paul, MN.

\section{Author Profiles}

\section{Manoj K. Shukla}

Dr. Manoj K Shukla is the Nakayama Chair and a Professor of Soil Physics at New Mexico State University, Las Cruces, NM, USA. Dr. Shukla is an Editor Book Review for Vadose Zone Journal and an Associate Editor for Soil Science Society America Journal. Dr. Shukla has co-authored more than 100 peer-reviewed Journal articles and three books. Dr. Shukla has so far graduated about 20 masters and $\mathrm{PhD}$ students as chair or co-chair of their graduate committee and another twenty as a member of their graduate committee. Dr. Shukla is a recipient of NACTA teaching Award of Excellence, Patricia Christmore faculty Teaching Award, and Water Resources Team Award.

\section{Blair L. Stringam}

Dr. Stringam is a Professor of Irrigation at New Mexico State University Department of Plant and Environmental Sciences. He has previously worked for the US Bureau of Reclamation, Montana State University, and the University of Idaho. A large portion of his teaching and research focuses on irrigation, crop water use, irrigation automation, and measurement of irrigation and water supply systems.

\section{Dawn M. VanLeeuwen}

Dawn M. VanLeeuwen received her PhD. in statistics from Oregon State University. She currently is a professor of applied statistics in the Department of Economics, Applied Statistics and International Business with a $60 \%$ joint appointment with the Agricultural Experiment Station. She currently enjoys teaching in the Applied Statistics graduate program and participating in collaborative research with fellow Agricultural Experiment Station researchers. These collaborations have resulted in many papers and presentations in a wide range of disciplines and service on numerous graduate student committees.

\section{Parmodh Sharma}

Parmodh Sharma a graduate student who completed a $\mathrm{PhD}$ in the Plant and Environmental Sciences, New Mexico State University, Las Cruces, NM. Dr. Sharma has published four refereed Journal articles. $\mathrm{He}$ is a recipient of Albert K. Dobrenz Award of Western Society of Crop Science for presentation of a graduate student paper in May 2007. He has received Graduate Assistantship award in 2008 and 2010, Mr.\&Mrs. Joe Parker scholarship during 20082009, and Graduate Assistant Tuition Fellowship award during his doctoral study. Parmodh was also awarded with the Outstanding PhD Graduate Student Award of New Mexico State University. 